\title{
COST DIFFERENCE BETWEEN INA-CBGS TARIFF AND HOSPITAL REAL COST IN THE TREATMENT OF TYPE 2 DIABETES MELLITUS WITHIN THE NATIONAL HEALTH INSURANCE PROGRAM
}

\author{
Amy Amanda Chitra Pahlawani'), Ascobat Gani' ${ }^{1)}$, Citra Kusuma Rahayu ${ }^{2)}$ \\ 1)Masters Program in Health Policy and Administration, \\ Faculty of Public Health, Universitas Indonesia \\ 2)Pharmacist Profession, Faculty of Mathematics and Sciences, \\ Universitas Islam Indonesia
}

\begin{abstract}
Background: The Indonesian Case Base Group (INA-CBGs) financing system within the National Health Insurance (NHI) program requires cost effectiveness analysis. This study aimed to investigate cost difference between INA-CBGs tariff and hospital real cost in the treatment of type 2 diabetes mellitus within the national health insurance program.

Subjects and Method: This was a cross-sectional study conducted at Yogyakarta City Hospital, Yogyakarta, Indonesia. A total sample of 9 type 2 DM patients were selected for this study. The DM patients under study were those using antidiuretic combination therapy within the NHI during 2017 to 2018 period. The data of DM patients were collected from the medical record.

Results: Seven patients (36.84\%) used antidiuretic combination of insulin aspart and insulin detemir. The highest effectiveness therapy was insulin combination therapy, long acting insulin, and a glycosidase, also combination therapy of fast acting insulin group, biguanid, and sulfonylureas, the effectiveness percentage of the two combination therapies were $100 \%$. The average direct medical cost of patients with type $2 \mathrm{DM}$ hospitalized in Yogyakarta City Hospital was Rp 3,539,118. Based on ACER, the most cost-effective therapy in class I was combination therapy for fast acting insulin and biguanid. In class II was combination therapy for fast acting insulin and long acting insulin. In class III was combination therapy for biguanid and sulfonylurea. Difference in real costs with INA-CBG's was Rp 37,715,931. There was no significant difference between the real costs and INA-CBG's $(\mathrm{p}=0.285)$.
\end{abstract}

Conclusion: There is no significant difference between the real cost and INA-CBGs.

Keywords: cost difference, diabetes mellitus, antidiuretic combination, INA-CBGs

\section{Correspondence:}

Amy Amanda Chitra Pahlawani. Masters Program in Health Policy and Administration, Faculty of Public Health, Universitas Indonesia, Depok, West Java. Email: amyamandacp@gmail.com Mobile: +628128077800o.

The $6^{\text {th }}$ International Conference on Public Health

Best Western Premier Hotel, Solo, Indonesia, October 23-24, 2019 | 283

https://doi.org/10.26911/the6thicph.04.45 